\title{
Population structure and gene flow of the Brazilian shrub Helicteres brevispira
}

\author{
EDIVANI V. FRANCESCHINELLI* $\uparrow \&$ RICHARD KESSELI $\$$ \\ $\uparrow$ Depto de Botânica - ICB, Universidade Federal de Minas Gerais, Campus Pampulha, Av. Antonio Carlos, 6627, Belo \\ Horizonte, MG, Brazil and $\ddagger$ Department of Biology, University of Massachusetts Boston, 100 Morrissey Blvd, \\ Boston, MA 02125, U.S.A.
}

\begin{abstract}
Helicteres brevispira is a pioneer species of the tropical riparian forest whose populations appear to cycle through episodes of extinction and recolonization. Therefore, genetic consequences of founding events may strongly affect the genetic structure of its populations. An analysis of $F$-statistics showed that the studied population of $H$. brevispira is genetically substructured with the highest values of $F_{\mathrm{ST}}$ found in areas of high plant densities. Spatial autocorrelation analysis showed that genetic patches have diameters of 3-6 m. Although pollinator movements are usually between plants which are 3-6 m apart, longer flights occur and the neighbourhood area is estimated to have a diameter of $15 \mathrm{~m}$. This suggests that genetic patches are smaller than the neighbourhood area. Seed dispersal is limited, mostly less than $2 \mathrm{~m}$ from the mother plants. Thus, short seed dispersal, seed dormancy and founder effects in the seed bank may be the most important determinants of genetic structure in populations of $H$. brevispira. Factors such as drift and inbreeding may also increase the level of substructure in this population, but the equilibrium model of isolation by distance does not fit our data.
\end{abstract}

Keywords: founder effect, hummingbird pollination, neighbourhood area, plant density, seed dispersal.

\section{Introduction}

Spatial distributions of genes and genotypes within plant populations have often revealed significant departures from randomness (Epperson, 1993). The spatial distribution of genetic variability within a population may strongly influence the evolutionary dynamics of that population (Lewontin, 1974). Population structure provides the substrate for local selective forces and this may promote the adaptive evolution of different traits in a species. Population structure may also represent a first step towards speciation (Lewontin, 1974).

A well-characterized evolutionary process is isolation by distance, first studied by Wright (1943). In plants, the limited distances of pollen and seed dispersal contribute to population substructure which may increase the frequency of consanguineous matings within demes and enhance drift among them (Wright, 1943).

In many species, local populations have a rapid turnover and an equilibrium among forces such as drift, gene flow, selection and nonrandom mating may not be

*Correspondence. E-mail: edivani@mono.icb.ufmg.br

(C) 1999 The Genetical Society of Great Britain. achieved (McCauley, 1993). Wright (1940) was the first to suggest that local extinction and recolonization can increase population differentiation. He noted that the number of individuals colonizing a patch is likely to be much smaller than the local carrying capacity, which implies small founding populations. Alternatively, Slatkin (1977) suggested that frequent extinctions and recolonizations of local populations may increase gene flow and limit the genetic differentiation of populations. Wade \& McCauley (1988) noted that founding effects can either enhance or decrease genetic variance among groups and showed that the structure among demes is critically affected by factors such as number and origin of founding individuals, the extinction rate, and number of patch habitats.

We are investigating the spatial genetic patterns in Helicteres brevispira St. Hil., a shrub that occurs in the edge and gaps of tropical riparian forests. It is among the first shrubs to invade recently abandoned pastures (Gromboni-Guaratini, 1993) and thus serves as an important transition species during early successional stages of reforestation. Because turnover in colonizers is fast (Hubbel \& Foster, 1986), the populations last only one or two generations in a site. Thus, recolonization 
rates, the origin of colonizing seed and the time to extinction can be a very important determinants of population genetic structure and metapopulation dynamics. Here, using $F$-statistics and spatial autocorrelation analyses, we characterize the substructure of a population of $H$. brevispira. We scored plant densities and estimated seed and pollen dispersals to evaluate their effect on local population structure. Finally, we discuss the life history factors that may contribute to the observed patterns of genetic diversity and differentiation.

\section{Materials and methods}

\section{Study site, species and field work}

The fieldwork was conducted at the Mogi Guaçú Ecological Reserve in São Paulo State, Brazil, at $22^{\circ} 18^{\prime} \mathrm{S}, 47^{\circ} 13^{\prime} \mathrm{W}$. The reserve comprises 997 ha of gallery forest and savannah vegetation. This area has a tropical climate with alternating cool, dry and hot, rainy seasons.

Helicteres brevispira is a shrub or small tree (1-7 m tall), and is restricted to the tropical regions of South America. The species has a patchy distribution with individuals clustered in gaps that are in transition to 'cerrado' (Brazilian savannah) or in linear populations along the forest edge. The studied population of 325 adults in a locally patchy distribution (Fig. 1) is isolated from other populations by at least $1 \mathrm{~km}$. Every adult plant of the studied population was mapped (Fig. 1). The map coordinates were triangulated from stakes $10 \mathrm{~m}$ apart.

Hummingbirds (Amazilia lactea and Chlorostilbon aureoventris) are probably the exclusive pollinators. The large flowers with stigmas and anthers separated from the floral nectary by $5 \mathrm{~cm}$ limit successful pollinations by other, infrequent visitors (Franceschinelli, 1989; Franceschinelli \& Bawa, unpubl. data). Fruits are capsules with 30-60 small seeds, which have dormancy (Gromboni-Guaratini, 1993).

To estimate pollen flow among plants, we observed hummingbird flights for 18 days during the peak of the flowering season of 1992. Every morning at the time of peak activity (from 08.00 to 11.00 hours), one hummingbird was captured and marked with a coloured ring and the sequence of plants visited was recorded.

To estimate seed dispersal, four transects with four adjacent seed collectors were placed at $90^{\circ}$ angles from the stems of six isolated plants. Each collector was a shallow box, $1 \mathrm{~m} \times 1 \mathrm{~m}$, with a fine mesh bottom, elevated $10 \mathrm{~cm}$ above the ground. The sample plants did not belong to the studied population and were separated by at least $50 \mathrm{~m}$ from any other conspecifics to guarantee that all seeds were derived from a single plant.

\section{Isozyme analyses}

New leaves were sampled from 298 individuals of the studied population. The leaf material was transported in liquid nitrogen from Brazil to the University of Massachusetts, Boston and stored at $-80^{\circ} \mathrm{C}$ until enzyme extraction. A small piece of each leaf was ground in liquid nitrogen and the powdered tissue was mixed with extraction buffer ( $1 \mathrm{~mm}$ EDTA, $10 \mathrm{~mm} \mathrm{KCl,} 20 \mathrm{~mm}$ $\mathrm{MgCl}_{2}, 0.03$ mм NADP, 0.03 NAD, 4\% PVP-40, 10\% glycerol, and $0.1 \mathrm{M} \mathrm{NaPO}_{4}, \mathrm{pH} 7.5$ ) and absorbed onto filter paper wicks.

Twenty-six enzyme systems were screened with three electrophoretic buffers. Seven enzyme systems showed simple banding patterns and could be reliably scored: phosphoglucomutase (PGM, EC 5.4.2.2), uridine diphosphoglucose pyrophosphorylase (UGPP, EC 2.7.7.9), aconitate hydratase (ACO, EC 4.2.1.3), isocitrate dehydrogenase (IDH, EC 1.1.1.41), glucose-6-phosphate isomerase (PGI, EC 5.3.1.9), triose-phosphate isomerase (TPI, EC 5.3.1.1), and 6-phosphogluconic dehydrogenase (6PG, EC 1.1.1.44). PGM, UGPP, ACO, IDH and 6PG were resolved on a morpholine citrate buffer system at pH 7.8 (Clayton \& Tretiak, 1972). PGI and TPI were assayed on a lithium borate buffer at pH 8.3 (Soltis et al., 1983).

Locus banding patterns were consistent with typical subunit structures. Polymorphic loci conformed to Mendelian expectations for segregation in open-pollinated progeny arrays (Franceschinelli \& Bawa, pers. comm.). Different loci and alleles for a given system were designated sequentially, with the lowest number corresponding to the most anodally migrating locus or allele.

\section{Data analyses}

Neighbourhood area $\left(A_{\mathrm{N}}\right)$ was calculated using Crawford's (1984) formula, $A_{\mathrm{N}}=4 \pi\left[t\left(\sigma_{\mathrm{p}}\right)^{2} / 2+\left(\sigma_{\mathrm{s}}\right)^{2}\right]$ where $t$ is outcrossing rate and $\left(\sigma_{\mathrm{p}}\right)^{2}$ and $\left(\sigma_{\mathrm{s}}\right)^{2}$ are the axial dispersal variances of the pollen and seed, respectively. Pollen flow was measured from absolute distances and $\left(\sigma_{\mathrm{p}}\right)^{2}=1 / 2 \sum p^{2} / n_{\mathrm{p}}$, where $p$ is the distance of each pollinator movement and $n_{\mathrm{p}}$ is the total number of events. Seed flow was measured from axial distances and $\left(\sigma_{\mathrm{s}}\right)^{2}=\sum s^{2} / n_{\mathrm{s}}$, where $s$ is the seed dispersal distance measured along a single axis and $n_{\mathrm{s}}$ is the number of seed flow events. Effective neighbourhood size (Crawford, 1984) is $N_{\mathrm{e}}=A_{\mathrm{N}} d_{\mathrm{e}}$, where the effective density $d_{\mathrm{e}}=d(1+t) / 2$.

Standard measures of allozyme diversity were calculated: the proportion of polymorphic loci $\left(P_{0.99}\right)$, 
Fig. 1 Map of the population of Helicteres brevispira showing the location of the plots. The three size categories of plots had 20, 10 and $5 \mathrm{~m}$ diameters. The population was divided into three regions and the genetic substructure among the $10 \mathrm{~m}$ diameter plots (labelled Plots 1-20) within each region was compared.

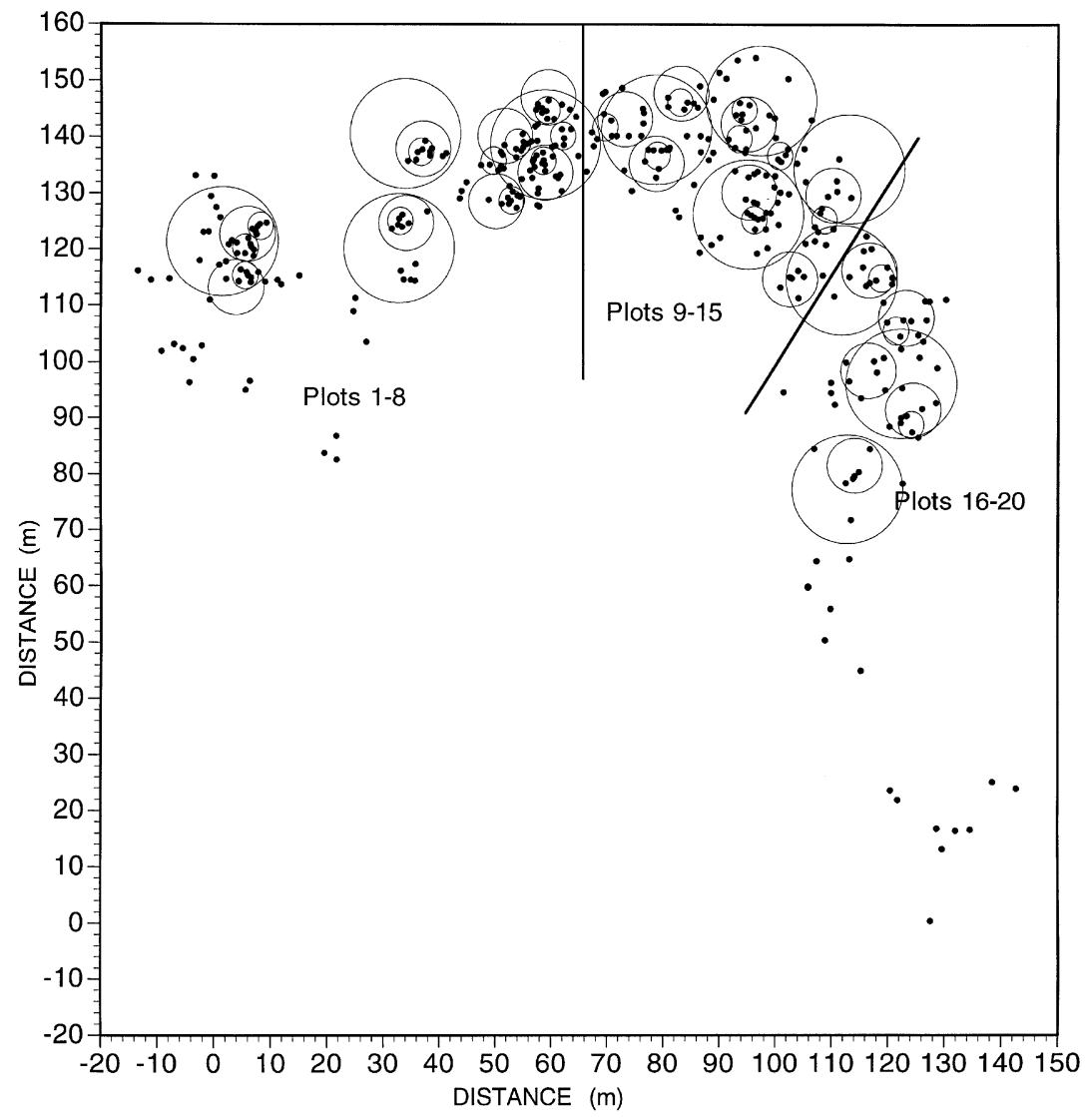

observed heterozygosity $(H)$, the effective number of alleles $\left(A_{\mathrm{e}}=1 / \sum p_{i}{ }^{2}\right)$ and the expected heterozygosity $\left(H_{\mathrm{e}}=1-\sum p_{i}^{2}\right)$.

Wright's (1943) $F$-statistics $\left(F_{\mathrm{IS}}, F_{\mathrm{ST}}\right.$ and $F_{\mathrm{IT})}$ were used to measure hierarchical population structure and were calculated by the methods of Weir \& Cockerham (1984). Jackknifing and bootstrapping were used for combining information over alleles and loci and for estimating sample variances and confidence intervals. Weir's (1990) computer program 'diploid.dat' was used for these analyses.

To examine the level of substructure in H. brevispira, we divided the population into overlapping plots of 20 , 10 and $5 \mathrm{~m}$ diameters (Fig. 1). Average plant density in these plots was $0.08( \pm$ SD 0.04$), 0.14( \pm 0.05)$ and 0.36 $( \pm 0.09)$ plants $/ \mathrm{m}^{2}$, respectively. The position of these plots was defined by the spatial distribution of individuals in the population map. We avoided plots with small sample sizes and considered only plots with five or more plants. The $10 \mathrm{~m}$ diameter plots were also grouped into three areas to test for variation in population substructure within the population (Fig. 1).

The spatial structuring of allozyme variation was quantified by Moran's I (Sokal \& Oden, 1978), for which we used a computer program written by Dr Eugene Gallegher (University of Massachusetts, Boston). Each allozyme was analysed separately, with individuals assigned allele frequency values of $0.0,0.5$ (heterozygote) and 1.0. As applied in this study, Moran's I quantifies the genetic similarity of pairs of spatially adjacent individuals relative to the population sampled as a whole. The value of $I$ ranges between +1 (complete positive autocorrelation, i.e. paired individuals have identical values) and -1 (complete negative autocorrelation). Under the null hypothesis of complete spatial randomness (i.e. no spatial autocorrelation), $I$ is asymptotically Gaussian with an expected value of zero. The significance level of $I$ was determined by a randomization test; this provides a more stringent test of significance than other methods (E. Gallegher, pers. comm.). Five thousand permutations were carried out to estimate variances and confidence intervals. For this analysis, genotypes of 297 plants were used. Each distance class in the analysis corresponded to $1 \mathrm{~m}$ diameter.

\section{Results}

\section{Allele frequency and genetic variation}

Among the seven enzyme systems assayed, six showed polymorphic banding patterns and one, PGM, was monomorphic. Seven of the eight loci were polymorphic 
$(P=0.88)$ and, when compared to other tropical species, moderate levels of genetic diversity $\left(H_{\mathrm{e}}=0.24\right)$ were present (Table 1). Two loci were excluded from the $F$-statistics and spatial autocorrelation analyses: Aco because of missing data for many individuals and $6 \mathrm{Pgl}$ because of the low level of polymorphism.

\section{Gene flow}

Observations of pollinator flight distance were possible only for territorial hummingbirds, which were foraging in the high density areas of $H$. brevispira. Marked hummingbirds were observed defending the same foraging area for several days. Seven different hummingbirds were monitored and 81 flights between 19 different plants were recorded. Four of the birds were male Chlorostilbon aureoventris and three were Amazilia lactea of unknown sex. These birds defended plants which were within areas of $7-15 \mathrm{~m}^{2}$. However, for $20 \%$ of their flights, the birds left their territories and visited plants in other areas. Direct observations indicated that most pollinator flights $(62 \%)$ were restricted to $3 \mathrm{~m}$, though movements of 9-30 m were observed (Fig. 2). Seed dispersal was even more limited with the 3944 seeds

Table 1 Indices of genetic variation for Helicteres brevispira

\begin{tabular}{|c|c|c|c|c|}
\hline Locus & $A$ & $\begin{array}{c}\text { Allele } \\
\text { frequencies }\end{array}$ & $A_{\mathrm{e}}$ & $H_{\mathrm{e}}$ \\
\hline Pgm & 1 & 1.0 & 1 & 0 \\
\hline $6 P g 1$ & 3 & $\begin{array}{l}0.02 \\
0.96 \\
0.02\end{array}$ & 1.10 & 0.09 \\
\hline $6 P g 2$ & 2 & $\begin{array}{l}0.33 \\
0.67\end{array}$ & 1.80 & 0.45 \\
\hline$I d h$ & 3 & $\begin{array}{l}0.04 \\
0.87 \\
0.08\end{array}$ & 1.29 & 0.23 \\
\hline$P g i$ & 4 & $\begin{array}{l}0.04 \\
0.61 \\
0.25 \\
0.10\end{array}$ & 2.24 & 0.55 \\
\hline$U g p p$ & 3 & $\begin{array}{l}0.01 \\
0.92 \\
0.07\end{array}$ & 1.18 & 0.15 \\
\hline Aco & 2 & $\begin{array}{l}0.84 \\
0.16\end{array}$ & 1.37 & 0.27 \\
\hline Tpi & 2 & $\begin{array}{l}0.90 \\
0.10\end{array}$ & 1.22 & 0.18 \\
\hline $\begin{array}{l}\text { Mean } \\
( \pm \mathrm{SD})\end{array}$ & $\begin{array}{l}2.5 \\
(1.19)\end{array}$ & - & $\begin{array}{c}1.40 \\
(0.42)\end{array}$ & $\begin{array}{c}0.24 \\
(0.18)\end{array}$ \\
\hline
\end{tabular}

$A$, number of alleles; $A_{\mathrm{e}}$, effective number of alleles; $H_{\mathrm{e}}$, expected heterozygosity.

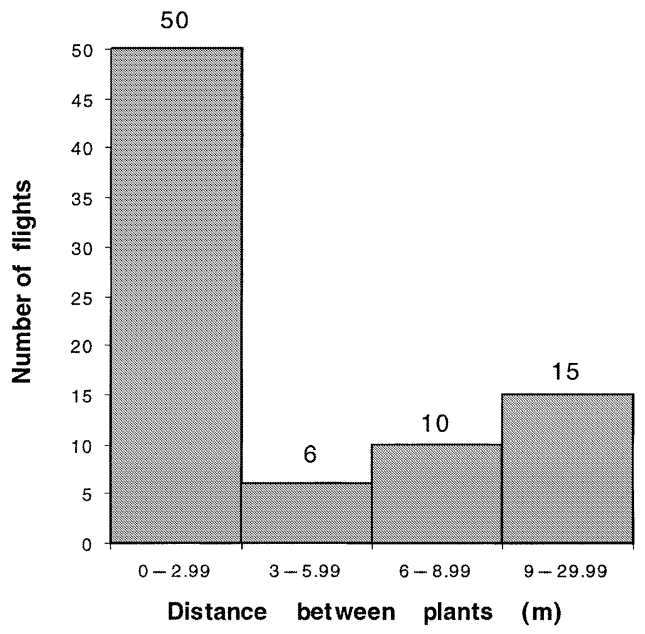

Fig. 2 Histogram of flight distances among plants of Helicteres brevispira for various hummingbird pollinators.

scored in the study averaging $1.6 \mathrm{~m}$ and only $13 \%$ travelling more than $2 \mathrm{~m}$ (Table 2). No secondary dispersal by animals was observed.

Using an outcrossing rate estimate of $t=0.68$ (Franceschinelli \& Bawa, unpubl. data) and the above dispersal data, we calculated neighbourhood area and size. The axial pollen and seed dispersal variances were $\sigma_{\mathrm{p}}^{2}=30.35$ and $\sigma_{\mathrm{s}}^{2}=3.18$, respectively. The estimated neighbourhood area is $A_{\mathrm{N}}=169.57 \mathrm{~m}^{2}$ or a circle with $7.35 \mathrm{~m}$ radius. Neighbourhood size $\left(N_{\mathrm{e}}\right)$ averaged 18-23 individuals depending on the neighbourhood density.

\section{Population structure}

This population of $H$. brevispira showed significant substructuring. Numerical resampling over loci (jackknifing and bootstrapping) showed that the multilocus values of $F_{\mathrm{ST}}$ differed significantly from zero $(P<0.05)$ for all plot sizes tested (5, 10 and $20 \mathrm{~m}$ diameters) (Table 3). The multilocus $F_{\mathrm{ST}}$ estimate was highest for the $5 \mathrm{~m}$ plots. Individual loci did not, however, show significant substructuring for $20 \mathrm{~m}$ diameter plots. All loci, except $I d h$, showed high $F_{\mathrm{ST}}$ values and generally

Table 2 Seed dispersal distances for Helicteres brevispira

\begin{tabular}{lrrrr}
\hline & \multicolumn{4}{c}{ Distance from source (m) } \\
\cline { 2 - 5 } & 1 & 2 & 3 & 4 \\
\hline Average no. & & & & \\
of seeds & 86.2 & 56.2 & 20 & 1.9 \\
$( \pm$ SD) & $(42.1)$ & $(16.7)$ & $(5.8)$ & $(1.2)$ \\
Proportion & 0.52 & 0.34 & 0.12 & 0.01 \\
\hline
\end{tabular}

(C) The Genetical Society of Great Britain, Heredity, 82, 355-363. 


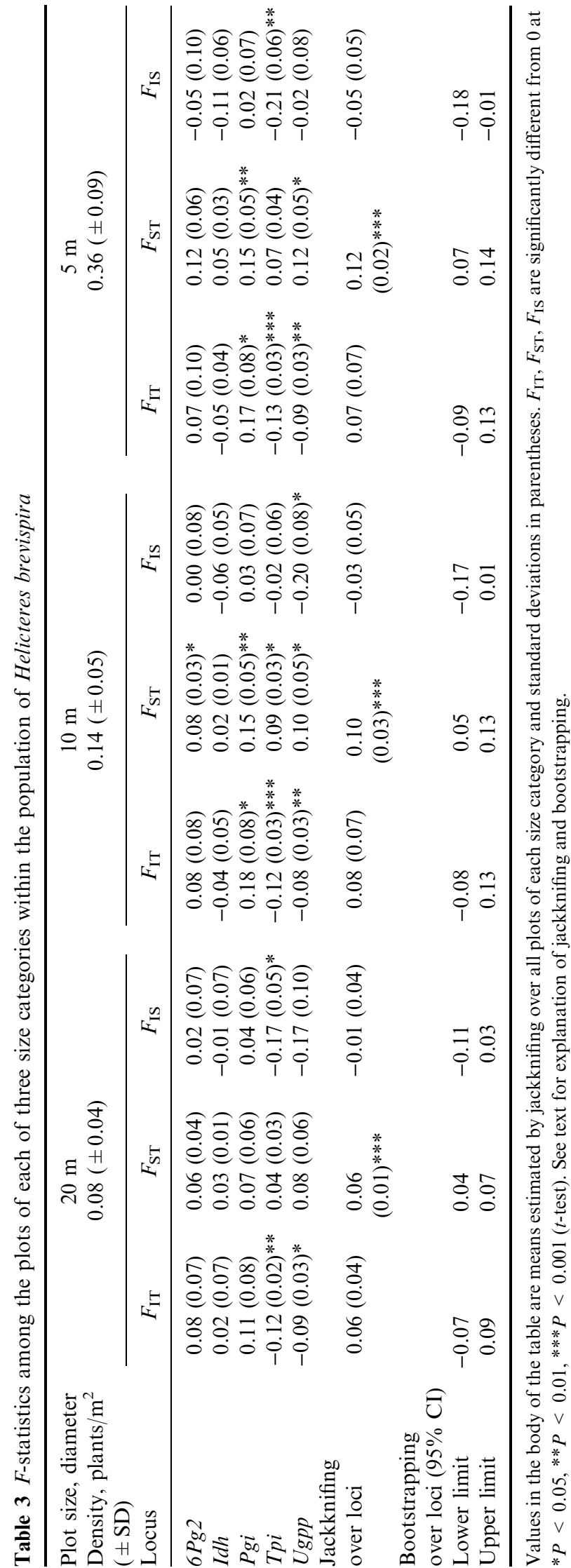

significant substructuring for the smaller plots; because of the small sample sizes in the $5 \mathrm{~m}$ plots, the variances were often higher and values of $F_{\mathrm{ST}}$ for some loci were only marginally significant $(P<0.10)$.

The degree of substructuring varied within the population (Table 4). Area 1 (plots 1-8), had the highest $F_{\mathrm{ST}}$ value $(0.16 \pm 0.05)$. Area 3 (plots 16-20) had the lowest value of $F_{\mathrm{ST}}(0.03 \pm 0.03)$ which did not differ significantly from 0.0 . Area 2 showed an intermediate value of $F_{\mathrm{ST}}(0.07 \pm 0.02)$. The $F_{\mathrm{ST}}$ values for areas 1 and 3 differed significantly from each other $(t$-test, $P<0.05)$ but not from the value in area 2 . These areas showed parallel differences in plant density. The densities in area $1\left(0.16 \pm 0.05\right.$ plants $\left./ \mathrm{m}^{2}\right)$ and area $3(0.09 \pm 0.02$ plants $\left./ \mathrm{m}^{2}\right)$ differed significantly from each other ( $t$-test, $P<0.01)$ but not from the density $(0.13 \pm 0.02$ plants/ $\mathrm{m}^{2}$ ) in area 2 .

For all loci combined, the inbreeding coefficients $F_{\text {IS }}$ and $F_{\mathrm{IT}}$ did not differ significantly from zero. The estimates of $F_{\mathrm{IS}}$ and $F_{\mathrm{IT}}$ for individual loci showed no consistent patterns and were generally nonsignificant as well. Tpi and Ugpp showed significant but negative values for each plot size. Only Pgi showed any significant positive values of $F_{\mathrm{IT}}$ (Table 3 ).

\section{Spatial autocorrelation analyses}

Using spatial autocorrelations, we detected high and significant values of Moran's $I$ in the first distance class for most allozymes of $H$. brevispira (Fig. 3). Of the nine alleles analysed, only $I d h^{2}$ and $T p i^{2}$ showed very weak and generally nonsignificant Moran's $I$-values. All other alleles showed significant substructure at the most local scales (first class $=1 \mathrm{~m}$ ) and most continued to exhibit positive autocorrelations at the third distance class. Alleles $U g p p^{2}$ and $U g p p^{3}$ showed the highest substructuring with significant values of Moran's $I$ extending to the sixth distance class. These results suggest that the population is substructured in genetic patches of 3-6 m diameter.

\section{Discussion}

Direct observations of pollinator movements and seed dispersal indicate that gene flow is limited in $H$. brevispira and that neighbourhood size and area is relatively small. Although some long-distance pollen flow is likely, given the bird vector (Fig. 2), most seems to be restricted to several metres and probably all seed flow is restricted to $3 \mathrm{~m}$ or less from the mother plant stem (Table 2). Helicteres brevispira does not have either specialized mechanisms for long-distance seed dispersal or secondary dispersal by animals; most seeds fall directly to the ground upon fruit dehiscence. Other studies 


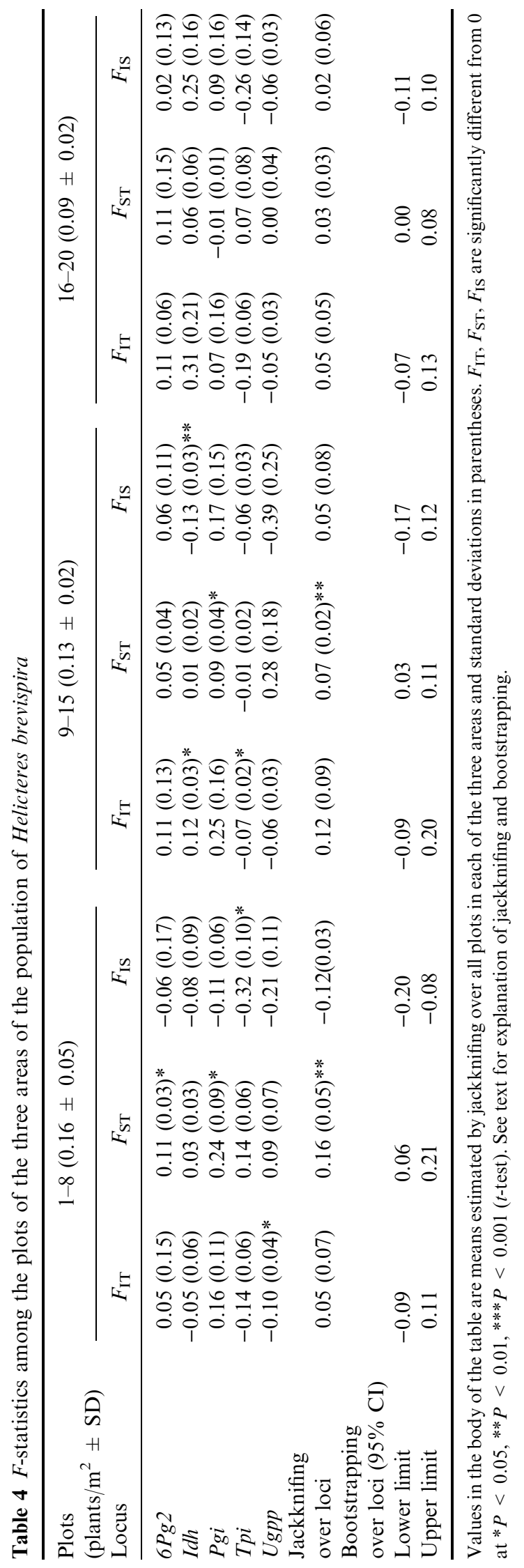

have shown that short seed dispersal is the main factor affecting variation in gene flow and population structure (Williams, 1994; Epperson \& Alvarez-Buylla, 1997). Considering the restricted pollen and seed dispersal in $H$. brevispira, we would predict strong substructuring in this population.

The genetic analyses of substructure corroborate the low gene flow observations in $H$. brevispira. Substructuring is detected by both $F$-statistics and spatial autocorrelation results (Table 3 and Fig. 3). The relative magnitude of genetic differentiation increases as the size of the sample plots decreases. Thus, sample plots of 5 and $10 \mathrm{~m}$ diameters have higher values of $F_{\mathrm{ST}}(0.12$ and 0.10 , respectively) than the $20 \mathrm{~m}$ plots $(0.06)$. For the spatial autocorrelation analyses the first and second distance classes show high and generally significant values of Moran's $I$ for most alleles (Fig. 3). Differences among loci can be caused by differences in selection (Campbell \& Dooley, 1992; Epperson, 1993) or other factors, including stochastic variation of allele frequencies (Slatkin \& Arter, 1991). These distance classes translate into patch sizes as small as 3-6 $\mathrm{m}$ in diameter. Other studies also have found substructure at fine scales for plant populations (see Epperson, 1995).

The level of substructure varies within the population of $H$. brevispira (Table 4). This variation seems to be directly correlated with plant density. The $F_{\mathrm{ST}}$ value is significantly different from zero and higher $\left(F_{\mathrm{ST}}=0.16\right)$ in the highest density plots $(1-8$ with $0.16 \pm 0.05$ plants $/ \mathrm{m}^{2}$ ) and nonsignificant and lower $\left(F_{\mathrm{ST}}=0.03\right)$ in the lowest density plots $(16-20$ with $0.09 \pm 0.02$ plants $/ \mathrm{m}^{2}$ ). Other authors have found similar positive correlations between density and structure (Ellstrand et al., 1978; Watkins \& Levin, 1990; Coates \& Sokolowski, 1992), though see Williams (1994) for exceptions.

\section{Population substructure, gene flow and life histories}

Correlations between outcrossing rates, plant densities, inbreeding and population structure have been examined in many taxa (Ellstrand et al., 1978; Watkins \& Levin, 1990; Coates \& Sokolowski, 1992; Karron et al., 1995). Additionally, the relationship between gene flow, neighbourhood area and size and patch dynamics has been investigated (Epperson, 1993, 1995). For $H$. brevispira we detected some expected and some unusual relationships among these population parameters. High substructure $\left(F_{\mathrm{ST}}=0.16 \pm 0.05\right)$ was associated with high densities and high outcrossing rates ( 0.65 and 0.68 ; Franceschinelli, pers. obs.) and an excess of heterozygotes $\left(F_{\mathrm{IS}}=-0.12 \pm 0.03\right)$, whereas low substructure $\left(F_{\mathrm{ST}}=0.03\right)$ was associated with low densities, low 
Fig. 3 Autocorrelation analyses of population substructure in Helicteres brevispira. Moran's I-values are plotted for each distance class (in metres). Filled symbols indicate significant values of Moran's $I$. The first five plots analyse the rare alleles of the five loci used in this component of the study. The sixth plot shows the average values of all loci. outcrossing rates $(0.48$ and 0.49 , Franceschinelli, pers. obs.) and no excess of heterozygotes $\left(F_{\mathrm{IS}}=0.02 \pm 0.03\right)$. Also, patch size, based on levels of substructure $\left(F_{\mathrm{ST}}\right)$ among plots of varying size and on autocorrelation analyses, seemed much smaller than expected, given our estimates of neighbourhood area. Several factors may explain these results. Changes in the behaviour of the hummingbirds with different plant densities seem to affect the outcrossing rates of $H$. brevispira. In low density areas, hummingbirds visit large numbers of flowers on each plant, which enhances geitonogamy (exchange of pollen among flowers of the same plant). Plants in high densities are visited mainly by territorialist hummingbirds which visit few flowers per plant. The small patch size as estimated by both $F$-statistics (highest $F_{\mathrm{ST}}$ in $5 \mathrm{~m}$ diameter plots) and autocorrelation (significance in patches of $6 \mathrm{~m}$ diameter or less) seems at odds with the larger estimates of neighbourhood area (15 $\mathrm{m}$ diameter). This suggests that other factors (e.g. selection) have a stronger influence on population structure than pollen flow and outcrossing or, more
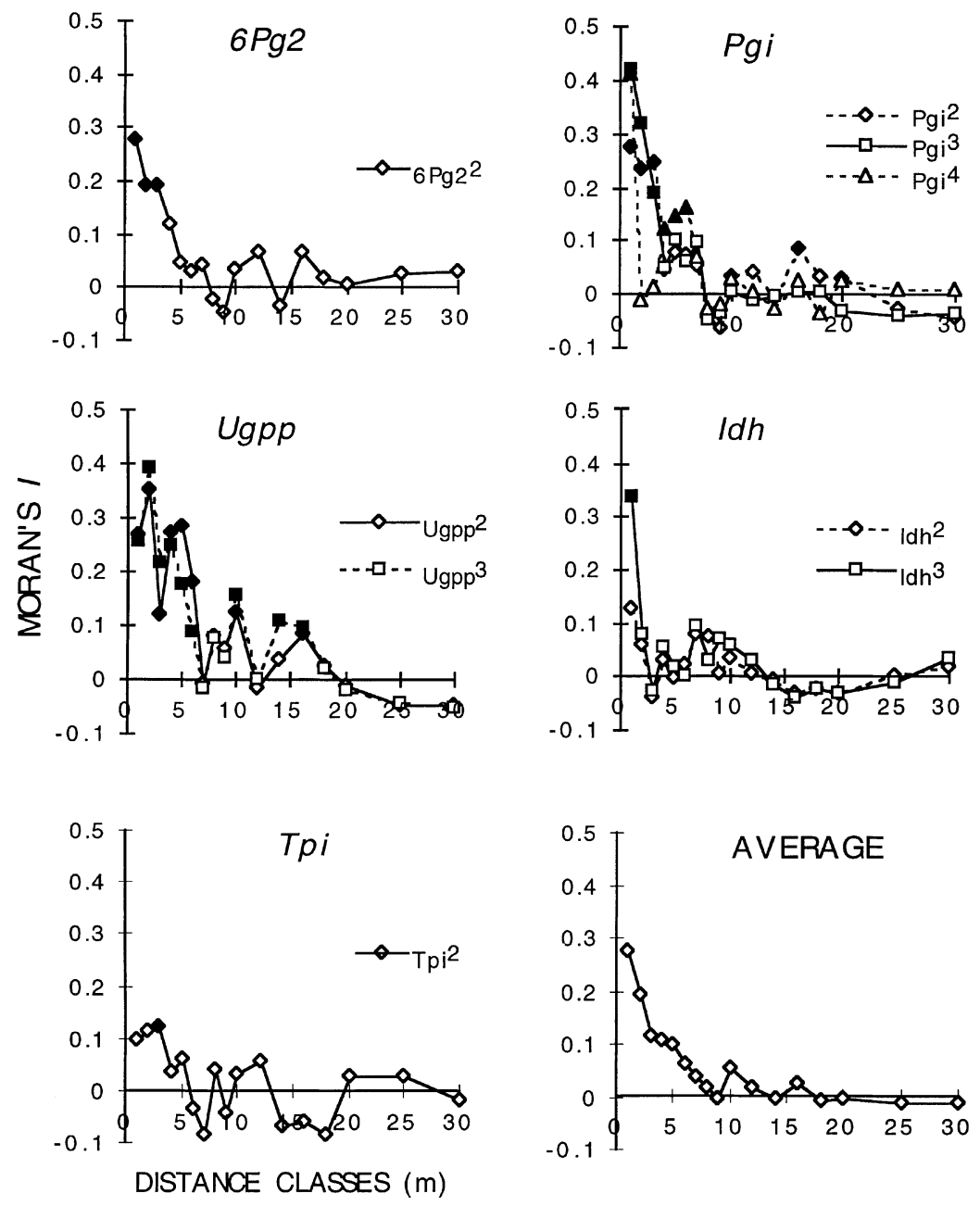

likely, that our estimates of gene flow and outcrossing in the extant population are decoupled from population structure because the system has not reached equilibrium.

Structured seed banks may be the primary determinant of the extant structure. The sampled population of $H$. brevispira occurs close to the riparian forest of the Mogi-Guaçu River. This population occupies an area that was clear-cut about 20 years ago for pasture and rice plantation. The area now belongs to the Ecological Reserve of Mogi-Guaçu, where agriculture and grazing have been prohibited for the past 10 years. Species from the original vegetation are slowly re-establishing and $H$. brevispira is one of the most frequent. Seeds of $H$. brevispira are common in the seed banks of this site (Gromboni-Guaratini, 1993). Thus, plants of the studied population were probably recruited from the seed banks. Because seed dispersal is limited in $H$. brevispira, kinstructured seed banks may be easily established in the soil. Helicteres brevispira is a colonizing species (Gromboni-Guaratini, 1993) and populations may survive for 
only a generation or two; too short for the establishment of an equilibrated population structure. Thus these structured seed banks may be the most important determinant of the genetic structure of these populations (McCauley, 1993).

\section{Patterns of population structure in plant species}

The population of $H$. brevispira showed moderate values of $F_{\mathrm{ST}}(0.06,0.10$ and 0.12$)$ compared to other plant species $\quad\left(F_{\mathrm{ST}}=0.007-0.455\right) \quad$ (Schaal, 1975; Waser, 1987; Eguiarte et al., 1992; Alvarez-Buylla \& Garay, 1994; Lokker et al., 1994; Williams, 1994). Most studies that include spatial autocorrelation analyses have found values of Moran's $I$ (between 0.05 and 0.20 ) equal to or less than that observed for $H$. brevispira $(I=0.09-0.42$ for positive significant values; Fig. 3). Various forms of selection (Waser, 1987; Campbell \& Dooley, 1992; Epperson \& Alvarez-Buylla, 1997), population bottlenecks (Lokker et al., 1994) and gene flow (Dewey \& Heywood, 1988; Eguiarte et al., 1992; Alvarez-Buylla \& Garay, 1994; Lokker et al., 1994; Williams, 1994) have been suggested as factors contributing to structure.

The low nonsignificant or negative values of $F_{\text {IT }}$ and $F_{\text {IS }}$ obtained for $H$. brevispira (Table 3 ) may be evidence of inbreeding depression in this population. A previous study has shown the presence of selective abortion of selffertilized embryos in Helicteres spp. (Franceschinelli, 1989). This selection and long-distance pollen flow may both decrease structure, whereas short seed dispersal, bottlenecks and drift may enhance it in H. brevispira. The data of this study represent a first attempt to characterize the population structure and life history of this early colonizing species. This information will aid the design and management of revegetation projects.

\section{Acknowledgements}

This work was partially supported by a CNPq Conselho Nacional de Desenvolvimento Científico e Tecnológico - grant to E.V.F. and by National Science Foundation grant DEB 9400147 to K. Bawa and R. Kesseli. Thanks to Eliane Oliveira for her help in the field. We are indebted to Drs Kamaljit Bawa, Michael Chase, Jeff Dole and Bryan Epperson and to Lelia Orrell and Cameron Moller for their assistance and advice. We are grateful to Drs Eugene Gallegher and Bruce S. Weir for the use of their computer programs. Finally, we thank Dr Terry Crawford and two anonymous reviewers for helpful comments on the manuscript.

\section{References}

Alvarez-BuYlla, E. R. AND Garay, A. A. 1994. Population genetic structure of Cecropia obtusifolia, a tropical pioneer tree species. Evolution, 48, 437-453.
CAMPBell, D. R. AND DOOLEY, J. L. 1992. The spatial scale of genetic differentiation in a hummingbird-pollinated plant: comparison with models of isolation by distance. Am. Nat., 139, 735-748.

ClAyton, J. W. AND TRETiAK, D. N. 1972. Amine-citrate buffers for $\mathrm{pH}$ control in starch gel electrophoresis. J. Fish. Res. Board Can., 29, 1169-1172.

COATES, D. C. AND SOKOLOwSKI, R. E. S. 1992. The mating system and patterns of genetic variation in Banksia cuneata A.S. George (Proteaceae). Heredity, 69, 11-20.

CRAWFORD, T. J. 1984. What is a population? In: Shorrocks, B. (ed.) Evolutionary Ecology, pp. 135-174. British Ecological Society Symposium no. 23. Blackwell Scientific Publications, Oxford.

DEWEY, S. E. AND HEYWOOD, J. S. 1988. Spatial genetic structure in a population of Psychotria nervosa. 1. Distribution of genotypes. Evolution, 42, 834-838.

EGUiARTE, L. E., PEREZ-NASSER, N. AND PIŇERO, D. 1992. Genetic structure, outcrossing rate and heterosis in $A s$ trocaryum mexicanum (tropical palm): implications for evolution and conservation. Heredity, 69, 217-228.

ELlSTRAND, N. C., TORRES, A. M. AND LEVIN, D. A. 1978. Density and the rate of apparent outcrossing in Helianthus annuus (Asteraceae). Syst. Bot., 3, 403-407.

EPPERSON, B. K. 1993. Recent advances in correlation studies of spatial patterns of genetic variation. Evol. Biol., 27, 95-155.

EPPERSON, B. K. 1995. Fine-scale spatial structure: correlations for individual genotypes differ from those for local gene frequencies. Evolution, 49, 1022-1026.

EPPERSON, B. K. AND ALVAREZ-BUYLLA, E. R. 1997. Limited seed dispersal and genetic structure in life stages of Cecropia obtusifolia. Evolution, 51, 275-282.

FRANCESCHINELLI, E. V. 1989. Biologia da reproducao de especies de Helicteres: $\mathrm{H}$. brevispira, $\mathrm{H}$. ovata $e \mathrm{H}$. sacarolha. M.Sc. Thesis, Universidade Estadual de Campinas, Campinas - SP, Brazil.

GROMBONI-GUARATINI, M. T. 1993. Banco de sementes de uma floresta ripária no Rio Mogi-Guacú SP. M.Sc. Thesis. Universidade Estadual de Campinas, Campinas SP, Brazil.

HUBbel, S. P. AND FOSTER, R. B. 1986. Canopy gaps and the dynamics of a neotropical forest. In: Crawley, M. J. (ed.) Plant Ecology, pp. 77-96. Blackwell Scientific Publications, Oxford.

KARRON, J., THUMSER, N., TUCKER, R. AND HESSENAUER, A. 1995. The influence of population density on outcrossing rates in Mimulus ringens. Heredity, 75, 175-180.

LEWONTIN, R. C. 1974. The Genetic Basis for Evolutionary Change. Columbia University Press, New York.

LOKKER, C., SUSKO, D., LOVETT DOUST, L. AND LOVETT DOUST, J. 1994. Population genetic structure of Vallisneria americana, a dioecious clonal macrophyte. Am. J. Bot., 81, 1004-1012.

MCCAULEY, D. E. 1993. Evolution in metapopulations with frequent local extinction and recolonization. Oxford Surveys in Evolutionary Biology, 9, 109-133.

SCHAAL, B. A. 1975. Population structure and local differentiation in Liatris cylindracea. Nature, 252, 703.

SLATKin, M. 1977. Gene flow and genetic drift in a species subject to frequent local extinction. Theor. Pop. Biol., 12, 253-262. 
SLATKIN, M. AND ARTER, H. E. 1991. Spatial autocorrelation methods in population genetics. Am. Nat., 138, 499-517.

SOKAL, R. R. AND ODEN, N. L. 1978. Spatial autocorrelation in biology. 1. Methodology. Biol. J. Linn. Soc., 10, 199-228.

SOlTIS, E. D., HAUfLER, C. H., DARROW, D. C. AND GASTONY, G. J. 1983. Starch gel electrophoresis of ferns: A compilation of grinding buffers, gel and electrode buffers, and staining schedules. Am. Fern J., 73, 9-27.

WADE, M. J. AND MCCAUlEY, D. E. 1988. Extinction and recolonization: their effects on the genetic variance among populations. Evolution, 42, 995-1005.

WASER, N. M. 1987. Spatial genetic heterogeneity in a population of the montane perennial plant Delphinium nelsonii. Heredity, 58, 249-256.
WATKINS, L. AND LEVIN, D. A. 1990. Outcrossing rates as related to plant density in Phlox drummondii. Heredity, 65, 81-89.

WEIR, B. S. 1990. Genetic Data Analysis. Sinauer, Sunderland, MA.

WEIR, B. S. AND COCKERHAM, C. C. 1984. Estimating $F$-statistics for the analysis of population structure. Evolution, 38, 13581370 .

WILliaMs, C. F. 1994. Genetic consequences of seed dispersal in three sympatric forest herbs. II. Microspatial genetic structure within populations. Evolution, 48, 1959-1972.

WRIGHT, s. 1940. Breeding structure of populations in relation to speciation. Am. Nat., 74, 232-248.

WRIGHT, s. 1943. Isolation by distance. Genetics, 28, 114 138. 